\title{
Reproductive Neuroendocrine Pathways of Social Behavior
}

\author{
Ishwar S. Parhar*, Satoshi Ogawa and Takayoshi Ubuka \\ Brain Research Institute, School of Medicine and Health Sciences, Monash University Malaysia, Bandar Sunway, Malaysia
}

OPEN ACCESS

Edited by:

Pierrette Gaudreau,

Centre Hospitalier de

I'Université de Montréal

Research Center, Canada

Reviewed by:

Patrick J. Ronan,

Veterans Administration

Research, USA

Matthieu Keller,

CNRS, France

*Correspondence:

Ishwar S. Parhar

ishwar@monash.edu

Specialty section:

This article was submitted to

Neuroendocrine Science,

a section of the journal

Frontiers in Endocrinology

Received: 16 December 2015 Accepted: 18 March 2016

Published: 31 March 2016

Citation:

Parhar IS, Ogawa S and Ubuka T (2016) Reproductive Neuroendocrine

Pathways of Social Behavior.

Front. Endocrinol. 7:28.

doi: 10.3389/fendo.2016.00028
Social behaviors are key components of reproduction, because they are essential for successful fertilization. Social behaviors, such as courtship, mating, and aggression, are strongly associated with sex steroids, such as testosterone, estradiol, and progesterone. Secretion of sex steroids from the gonads is regulated by the hypothalamuspituitary-gonadal (HPG) axis in vertebrates. Gonadotropin-releasing hormone $(\mathrm{GnRH})$ is a pivotal hypothalamic neuropeptide that stimulates gonadotropin release from the pituitary. In recent years, the role of neuropeptides containing the C-terminal Arg-Phe$\mathrm{NH}_{2}$ (RFamide peptides) has been emphasized in vertebrate reproduction. In particular, two key RFamide peptides, kisspeptin and gonadotropin-inhibitory hormone $(G n \mid H)$, emerged as critical accelerator and suppressor of gonadotropin secretion. Kisspeptin stimulates $\mathrm{GnRH}$ release by directly acting on $\mathrm{GnRH}$ neurons, whereas $\mathrm{GnlH}$ inhibits gonadotropin release by inhibiting kisspeptin, $\mathrm{GnRH}$ neurons, or pituitary gonadotropes. These neuropeptides can regulate social behavior by regulating the HPG axis. However, distribution of neuronal fibers of $\mathrm{GnRH}$, kisspeptin, and $\mathrm{GnlH}$ neurons is not limited within the hypothalamus, and the existence of extrahypothalamic neuronal fibers suggests direct control of social behavior within the brain. It has traditionally been shown that central administration of $\mathrm{GnRH}$ can stimulate female sexual behavior in rats. Recently, it was shown that Kiss1, one of the paralogs of kisspeptin peptide family, regulates fear responses in zebrafish and $\mathrm{GnIH}$ inhibits sociosexual behavior in birds. Here, we highlight recent findings regarding the role of $\mathrm{GnRH}$, kisspeptin, and $\mathrm{GnIH}$ in the regulation of social behaviors in fish, birds, and mammals and discuss their importance in future biological and biomedical research.

Keywords: RFamide peptides, aggression, depression, sex behaviors, anxiety

\section{INTRODUCTION}

Reproduction is an essential process in vertebrates, which consists of various aspects of physiological events throughout the lifespan, including fertilization, development, puberty, social and sexual behaviors, maturation, and aging. Reproductive functions are controlled by the hypothalamus-pituitary-gonadal (HPG) axis. The hypothalamus, a central brain region that is responsible for the control of reproduction, regulates pituitary hormone synthesis and release. Gonadotropin-releasing hormone $(\mathrm{GnRH})$ or luteinizing hormone ( $\mathrm{LH}$ )-releasing hormone is a pivotal hypothalamic neuropeptide that regulates vertebrate reproduction (1). In tetrapods, $\mathrm{GnRH}$ neurons are located in the preoptichypothalamic region and project to the median eminence to regulate gonadotropin synthesis and release from the anterior pituitary gland, which stimulates sex steroid secretion and gametogenesis. 
It was also classically shown that central administration of $\mathrm{GnRH}$ can stimulate female sexual behavior in rats $(2,3)$.

In recent years, the role of neuropeptides containing the C-terminal Arg-Phe- $\mathrm{NH}_{2}$ (RFamide peptides) has been emphasized in vertebrate reproduction. In particular, two key RFamide peptides: kisspeptin and gonadotropin-inhibitory hormone [(GnIH) also known as LPXRFamide peptides] emerged as critical regulators (accelerator and suppressor, respectively) of vertebrate reproduction. These neuropeptides have been identified in a variety of species, including non-mammalian vertebrates, and shown to have evolutionarily conserved functions (4). Although knowledge about the role of RFamide peptides in social behaviors is still limited, recent studies have shown that Kiss1, one of the paralogs of kisspeptin peptide family, regulates fear responses in zebrafish (5), and GnIH inhibits sociosexual behavior in birds (6-9).

Social behaviors are key components of reproductive functions, because they are essential for successful fertilization. As social behaviors, such as courtship, mating, and aggression, are strongly associated with sex steroids, such as testosterone, estradiol, and progesterone (10), hypothalamic neuropeptides can regulate social behaviors by regulating the HPG axis. However, neuronal fibers containing neuropeptides that regulate the HPG axis and their receptors are widely distributed outside of the hypothalamus, including limbic brain structures in the brain. Investigation of the neural mechanisms and functions of neuropeptides that regulate gonadotropin secretion in the regulation of social behavior has a potential to uncover fundamental regulatory mechanism of social behavior. Therefore, we highlight traditional and recent findings regarding the function of $\mathrm{GnRH}$, kisspeptin, and $\mathrm{GnIH}$ neuropeptides in the regulation of social behaviors in fish, birds, and mammals and discuss their importance for further biological and biomedical researches in this article.

\section{GONADOTROPIN-RELEASING HORMONE}

In the early 1970s, Schally's and Guillemin's groups independently reported the amino acid sequence of mammalian $\mathrm{GnRH}$ peptide that was extracted from pig and sheep hypothalami, respectively $(11,12)$ (Table 1). Orthologous peptides to mammalian GnRH, categorized as GnRH1, which have few substitutions in the amino acid sequence, have been identified in other vertebrates, such as guinea pig (13), chicken $(14,15)$, and sea bream (16) (Table 1). It was shown that the expression of GnRH1 precursor mRNA is developmentally and seasonally regulated in songbirds $(17,18)$. In addition to the hypothalamic GnRH1, there are nonhypothalamic types of GnRH (GnRH2 and GnRH3) and multiple GnRH receptors in most vertebrate species (19). GnRH2 is the most evolutionarily conserved form of $\mathrm{GnRH}$, which many vertebrate species possess the identical peptide that was first identified in the chicken (20) (Table 1). GnRH2 neuronal cell bodies exist in the midbrain in all vertebrates investigated (21). GnRH3 was first identified in the salmon (22) (Table 1). GnRH3 neurons are present in the terminal nerve ganglion, and neuronal fibers were localized at the junction of the olfactory nerve and the telencephalon in most teleost species (23). As these extrahypothalamic GnRH neural populations project their neural fibers throughout the brain, their primary role may be to regulate social behavior by modulating other neurons in the brain. Indeed, in marmoset monkey, musk shrew, and white-crowned sparrows, GnRH2 enhances female reproductive behavior (24-27). In goldfish, both GnRH2 and GnRH3 significantly stimulate female spawning behavior (28). In cichlid fish, terminal nerve GnRH3 neurons regulate male social behaviors, including nest building and territorial behaviors (29). A recent study in Japanese medaka revealed a novel function of terminal nerve GnRH3 neurons as a gate for activating mating preferences based on familiarity (30).

Traditionally, hypothalamic GnRH (GnRH1) has also been shown to regulate reproductive behaviors, including female lordosis (39) and male mating behavior (40) in rats. In addition to sexual behaviors, hypothalamic GnRH is also known to modulate other social behaviors. In rhesus monkeys, treatment with a GnRH-receptor antagonist Antide, during neonatal periods, alters their social behaviors, such as group in proximity and grooming behaviors (41). In various mammalian species,

\begin{tabular}{|c|c|c|c|c|}
\hline Vertebrates & Peptide family & Peptide name & Amino acid sequence & Reference \\
\hline \multirow[t]{3}{*}{ Mammals } & $\mathrm{GnRH}$ & $\begin{array}{l}\text { Mammalian } \mathrm{GnRH} \\
\text { Guinea pig } \mathrm{GnRH}\end{array}$ & $\begin{array}{l}\text { pQHWSYGLRPGamide } \\
\text { pQYWSYGVRPGamide }\end{array}$ & $\begin{array}{l}\text { Matsuo et al. (11) and Burgus et al. (12) } \\
\text { Jimenez-Liñan et al. (13) }\end{array}$ \\
\hline & Kisspeptin & $\begin{array}{l}\text { Human KISS } \\
\text { Mouse Kiss }\end{array}$ & $\begin{array}{l}\text { YNWNSFGLRFamide } \\
\text { YNWNSFGLRYamide }\end{array}$ & $\begin{array}{l}\text { Lee et al. (31) } \\
\text { Stafford et al. (32) }\end{array}$ \\
\hline & $\mathrm{GnIH}$ & $\begin{array}{l}\text { Human RFRP1 } \\
\text { Human RFRP3 }\end{array}$ & $\begin{array}{l}\text { MPHSFANLPLRFamide } \\
\text { VPNLPQRFamide }\end{array}$ & $\begin{array}{l}\text { Ubuka et al. (33) } \\
\text { Ubuka et al. (33) }\end{array}$ \\
\hline \multirow[t]{2}{*}{ Birds } & $\mathrm{GnRH}$ & $\begin{array}{l}\text { Chicken GnRH1 } \\
\text { Chicken GnRH2 }\end{array}$ & $\begin{array}{l}\text { pQHWSYGLQPGamide } \\
\text { pQHWSHGWYPGamide }\end{array}$ & $\begin{array}{l}\text { King and Millar (14) and Miyamoto et al. (15) } \\
\text { Miyamoto et al. (20) }\end{array}$ \\
\hline & $\mathrm{GnIH}$ & $\begin{array}{l}\text { Quail GnIH } \\
\text { Quail GnIH-RP2 }\end{array}$ & $\begin{array}{l}\text { SIKPSAYLPLRFamide } \\
\text { SSIQSSLLNLPQRFamide }\end{array}$ & $\begin{array}{l}\text { Tsutsui et al. (34) } \\
\text { Satake et al. (35) }\end{array}$ \\
\hline Teleost fishes & $\mathrm{GnRH}$ & $\begin{array}{l}\text { Sea bream } \mathrm{GnRH} 1 \\
\text { Salmon } \mathrm{GnRH} 3\end{array}$ & $\begin{array}{l}\text { PQHWSYGLSPGamide } \\
\text { pQHWSYGWLPGamide }\end{array}$ & $\begin{array}{l}\text { Powell et al. (16) } \\
\text { Sherwood et al. (22) }\end{array}$ \\
\hline
\end{tabular}


immunization or immunoneutralization against $\mathrm{GnRH}$ results in reduction of aggressiveness (42-44). These results, however, have traditionally been thought to be mainly due to reduction of gonadal hormone release and not due to reduced action of GnRH in the brain, as relatively longer treatment was required. However, accumulating evidences suggest possible direct action of GnRH1 within the brain as a neurotransmitter or a neuromodulator, because GnRH1 receptor is expressed outside of hypothalamus and pituitary (45-47). In male hamster, GnRH1 enhances the main olfactory input to the medial amygdala, which may be important for receiving conspecific reproductive chemosignals (48).

In addition to reproductive functions, $\mathrm{GnRH}$ is also associated with anxiety and mood disorders, such as depression, because adverse effects of GnRH agonists have been observed in women undergoing assisted reproductive treatment $(49,50)$. In rodent models, GnRH agonists exhibit anxiolytic- and antidepressantlike effects, whereas GnRH antagonists induce anxiogenic-like behavior $(51,52)$, although the neuronal mechanism underlying the role for $\mathrm{GnRH}$ in mediating anxiety and depression has not been understood well. One possibility is that GnRH may regulate other neuropeptides that mediate emotional behaviors and stress responses (53). Interactions between vasopressin, a stress hormone that mediates social- and anxiety-like behaviors, neurons and GnRH neurons have been observed in the supraoptic nucleus of monkeys (54). In rats, GnRH agonist stimulates the release of vasopressin from the neurohypophysis (55). It was shown that GnRH2 inhibits food intake (56), and the anorexigenic action of $\mathrm{GnRH} 2$ neuron is regulated by various neuropeptides, including $\alpha$-melanocyte-stimulating hormone and corticotropin-releasing hormone in goldfish (57).

\section{KISSPEPTIN}

Kisspeptin is a family of peptides encoded by the KISS1 gene, which includes metastin (kisspeptin-54) and kisspeptin-10 (4). Comparison of amino acid sequences of kisspeptin among vertebrate species shows that the $\mathrm{C}$-terminal 10 amino acid sequence is highly conserved, suggesting the importance of the core 10 amino acid region (4) (Table 1). The shortest endogenous 10 amino acid kisspeptin exerts equal receptor (GPR54)-binding activity as the other longer endogenous fragments $(58,59)$. In teleost fish, two forms of kisspeptin (Kiss1 and Kiss2) have been reported $(37,60)$ (Table 1). On the other hand, birds do not possess either kisspeptin or GPR54 gene (61).

Kisspeptin and its cognate receptor GPR54-signaling were reported to be involved in the stimulatory regulation of $\mathrm{GnRH}$ neurons (62-65). However, there are no defects in gender-specific sexual behaviors in GPR54-knockout mice as long as the appropriate sex steroid hormones are provided (66). Similarly, doublekisspeptin (kiss1 and kiss2) and kisspeptin receptors (kissr1 and kissr2) gene mutant lines are capable of achieving successful reproduction in zebrafish (67). These observations suggest that the central kisspeptin-GPR54 system is not essential for direct regulation of sexual behaviors.

Recently, we have identified Kiss 1 gene expressed in the ventral habenula $(\mathrm{vHb})$ in the modulation of serotonin $(5-\mathrm{HT})$ neurons and fear responses in the zebrafish $(5,68)$. Expression of Kiss1 gene was also shown in the medial amygdala, a fear-regulating region in rodents (69). Furthermore, central administration of kisspeptin-13 increased basal corticosterone levels and induced hyperthermia upregulating motor behavior, causing anxiety in rats (70). In mice, kisspeptin-13 showed antidepressant-like effects in a modified forced swimming test via adrenergic and serotonergic receptors (71). It has also been shown that kisspeptin-13 facilitates learning and memory consolidation in a passive avoidance paradigm via various neurotransmitters in mice (72). Our very recent findings in the zebrafish suggest the interaction between the vHb-expressing Kiss 1 and the 5-HT system in the modulation of alarm substance-evoked fear responses mediated via two serotonin receptor subtypes (73). These results suggest that kisspeptin can act on several brain regions to facilitate a variety of social behaviors via interaction with different types of neurotransmitters.

\section{GONADOTROPIN-INHIBITORY HORMONE}

Gonadotropin-inhibitory hormone has been discovered as a novel hypothalamic RFamide peptide that inhibits $\mathrm{LH}$ release in birds $(34,74)$. GnIH is also named RFamide-related peptide (RFRP) in mammals (75). GnIH orthologous peptides have characteristic LPXRFamide (X = L or Q) amino acid sequence at their C-termini. Endogenous $\mathrm{GnIH}$ peptides were identified in humans (33), quail $(34,35)$, goldfish $(38)$, and in other vertebrates (74) (Table 1). The presence of orthologous $\mathrm{GnIH}$ receptor (GPR147) has also been demonstrated in various vertebrate species, suggesting that the GnIH-GPR147 signaling is evolutionarily conserved $(76,77)$. GnIH neurons terminate on GnRH neurons as well as kisspeptin neurons and these neurons express GPR147 (74, 78, 79) (Figure 1). In addition, GnIH-GPR147 signaling is regulated by various factors, such as natural and social environmental cues (79-81) and stress (82, 83), suggesting that $\mathrm{GnIH}$ is one of the mediators of favorable and unfavorable external stimuli (4). GnIH and GPR147 have been cloned and localized, and their functions have also been studied in several teleost species. However, the role of fish GnIH-GPR147 signaling remains inconclusive, because the physiological properties of fish LPXRFa are variable depending on reproductive condition and season.

Because $\mathrm{GnIH}$ neurons terminate in the close proximity of GnRH2 neurons $(78,91)$ and GnRH2 neurons express GPR147 (78), GnIH may inhibit reproductive behavior by inhibiting GnRH2 neuronal activity. In line with this hypothesis, Bentley et al. (92) showed that centrally administered $\mathrm{GnIH}$ inhibits copulation solicitation in estrogen-primed female white-crowned sparrows exposed to the song of males. Ubuka et al. (6) investigated the effect of RNA interference (RNAi) of the GnIH gene on the behavior of male and female white-crowned sparrows. GnIH RNAi reduced resting time, spontaneous production of complex vocalizations, and stimulated brief agonistic vocalizations. $\mathrm{GnIH}$ RNAi further enhanced song production in male birds when they were challenged by playbacks of novel male songs. Because these behaviors resembled behavior of breeding birds during 

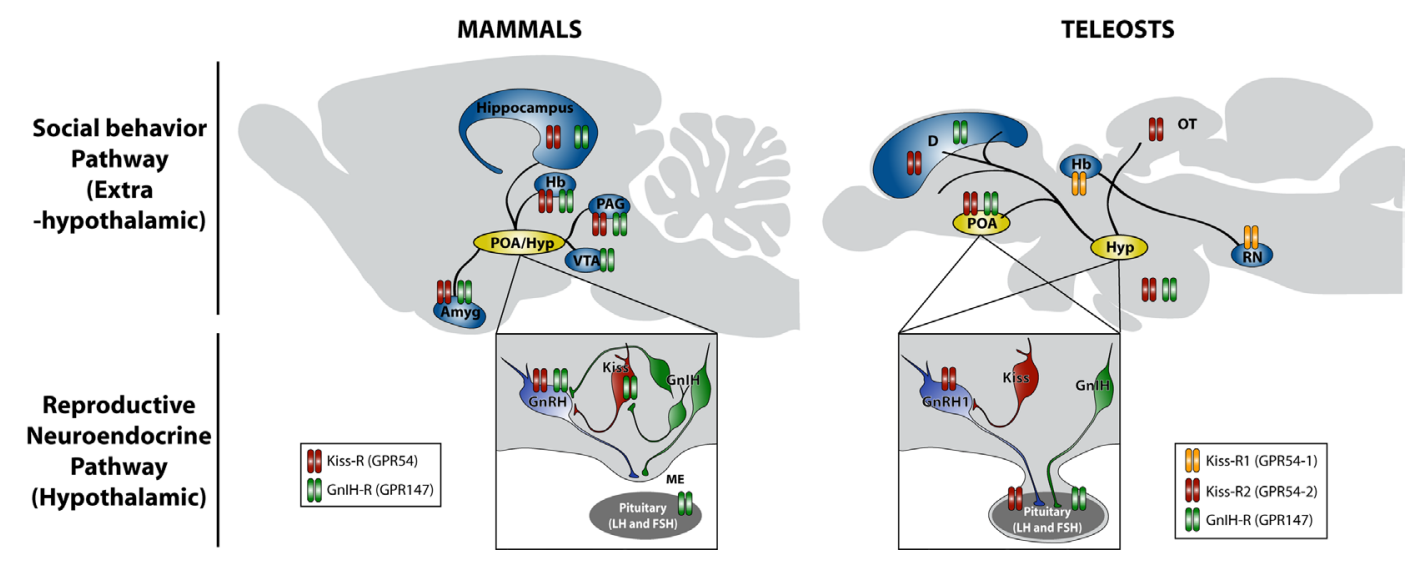

FIGURE 1 | Schematic model of actions of kisspeptin and GnIH in the regulation of social behavior in mammals and teleosts. Neuronal cell bodies producing gonadotropin-releasing hormone $(\mathrm{GnRH})$, kisspeptin (Kiss), and gonadotropin-inhibitory hormone $(\mathrm{Gn} H \mathrm{H})$ are located in the preoptic area (POA) and hypothalamic (Hyp) region. GnRH is secreted at the median eminence (ME) in mammals, whereas GnRH1 is directly secreted in the pituitary in teleosts, and they regulate gonadotropin ( $\mathrm{LH}$ and $\mathrm{FSH}$ ) synthesis and release from the pituitary gland, which stimulates sex steroid synthesis and gametogenesis in the gonads. Sex steroids feedback to the brain and construct neuronal architecture and modulate the activity of neurons, which regulate the expression of social behavior, such as courtship, mating, and aggression. Kiss neurons stimulate $\mathrm{GnRH}$ and $\mathrm{GnRH} 1$ release in mammals and teleosts, respectively. GnlH neurons inhibit the activity of $\mathrm{GnRH}$ and Kiss neurons as well as pituitary gonadotropin secretion in mammals. On the other hand, GnIH neurons terminate in the pituitary in teleosts. In addition to this reproductive neuroendocrine (hypothalamic) pathway, neuronal fibers containing Kiss and GnlH are found in extrahypothalamic regions, such as amygdala (Amyg), hippocampus, habenula (Hb), periaqueductal gray (PAG), and ventral tegmental area (VTA) in mammals and also dorsal telencephalic area (D), optic tectum (OT), and raphe nuclei (RN) in teleosts, which can directly regulate social behavior by acting within the brain (social behavior pathway). Neuronal fiber distributions of Kiss and GnlH neurons as well as locations of kisspeptin receptor (Kiss-R: GPR54) and GnlH receptor (GnlH-R: GPR147) in mammals are based on Tena-Sempere (84), Lehman et al. (85), Tsutsui and Ubuka (86), and Ubuka et al. (74). Neuronal fiber distributions of Kiss and GnlH neurons as well as locations of kisspeptin receptor (Kiss-R1: GPR54-1 and Kiss-R2: GPR54-2) and GnlH receptor (GnIH-R: GPR147) in teleosts are based on Escobar et al. (87), Qi et al. (88), Nathan et al. (73), Parhar et al. (89), and Grone et al. (90).

territorial defense, it was suggested that GnIH gene silencing induces arousal (6). It was recently shown that $\mathrm{GnIH}$ directly activates aromatase neurons in the preoptic area and increases neuroestrogen synthesis beyond its optimum concentration for the expression of sociosexual behavior of male birds (8). Johnson et al. (93) showed that central administration of RFRP-3 significantly suppresses all facets of male sex behavior in rats. Central administration of $\mathrm{GnIH}$ reduced sexual motivation and vaginal scent marking, but not lordosis behavior in female hamsters (94). On the contrary, there was no effect of $\mathrm{GnIH}$ on sexual behavior in non-human primates and ewes (95), which could be due to different injection conditions or social or reproductive status of the animals used.

\section{REGULATION OF REPRODUCTIVE NEUROENDOCRINE PATHWAY BY SOCIAL INTERACTION}

Social interactions have significant effects on reproductive physiology and behavior in vertebrates $(7,96,97)$. Male courtship behavior can greatly enhance the reproductive activity of female birds (98). Maney et al. (99) investigated the effect of male song on the rapid changes in $\mathrm{LH}$ and the induction of the immediate early gene Egr-1 in GnRH1 neurons in female whitethroated sparrows. However, although male song induced LH release, it did not alter Egr-1 expression in GnRH1 neurons (99). Calisi et al. (100) manipulated nesting opportunities for pairs of songbirds and measured GnIH mRNA and GnIH content, as well as GnRH1 content and plasma testosterone concentration. The birds with nest boxes had significantly fewer numbers of GnIH cells than those without nest boxes, whereas GnRH1 content and testosterone concentration did not vary with nest box ownership, suggesting that $\mathrm{GnIH}$ may modulate reproductive behaviors without changing the HPG axis in response to social environment (100).

Olfactory cues significantly impact sexual attraction and behavior in mammals (101). The chemosignals that act between members of the same species and triggering short-term behavioral responses or long-term physiological changes are termed pheromones $(102,103)$. When prepubertal females are exposed to pheromones of sexually mature males, puberty onset is accelerated in rodents (104). Another example of pheromonal stimulation of reproductive activity is the "male effect" in domestic ungulates, sheep, and goat (103). If anestrus females are exposed to a male, their HPG axis will be reactivated leading to ovulation. De Bond et al. (105) showed that male introduction leads to elevated $\mathrm{LH}$ pulse amplitude and frequency in a non-breeding female. However, central infusion of kisspeptin antagonist in advance abolished the effect of male exposure on LH secretion, suggesting that the "male effect" is mediated by kisspeptin signaling in ewes (105). Murata et al. (106) showed that brief exposure of male pheromone induces multiple-unit activity at close proximity to kisspeptin neurons in the goat arcuate nucleus, a brain region that is thought to be the site of $\mathrm{GnRH}$ pulse generator (107). 


\section{CLINICAL PERSPECTIVES OF NEUROPEPTIDES REGULATING REPRODUCTION IN THE TREATMENT OF MOOD, PAIN, OR STRESS-RELATED DISORDERS}

During reproductive aging and reproductive cycles, plasma steroid levels alter considerably and cause significant influences on various aspects of physiological functions, including mental and cognitive functions. For example, it is well known that many women have fluctuations in mood and libido in conjunction with phases of the menstrual cycle. Accordingly, failure in homeostatic control of the HPG axis leads to disorders in mood and libido. Neuropeptides and their receptors have been recognized as therapeutic targets for various mental disorders, such as mood, depression, and anxiety $(53,108,109)$. Recently, RFamide peptides have been recognized as new therapeutic targets $(110,111)$. Kisspeptin has recently been utilized for treatment of women with reproductive dysfunctions, although there are still very limited clinical cases (112-115). It was reported that citalopram, a potent selective serotonin reuptake inhibitor that is used as an antidepressant but causes sexual dysfunction, induced inhibition of sexual behavior involves stimulation of GnIH neurons through serotonin receptors in the rat (116), suggesting the use of $\mathrm{GnIH}$ receptor antagonist in the treatment of sexual dysfunction.

It is thought that GnIH gene and NPFF, a neuropeptide that has a PQRFamide motif at its C-terminal and involved in pain modulation, gene have diverged from a common ancestral gene through gene duplication $(117,118)$. It is also thought that GPR147 and GPR74, NPFF receptor, are paralogous $(76,119)$. Mammalian RFamide peptides, GnIH (RFRP-1 and -3), neuropeptides $\mathrm{AF}$ and $\mathrm{FF}$, prolactin-releasing peptides, kisspeptin, and QRFP/26RFa peptides are considered endogenous ligands for NPFF1 (GPR147), NPFF2 (GPR74), GPR10, GPR54, and GPR103, respectively (74). Elhabazi et al. (120) showed that all RFamide peptides efficiently activate GPR147 and GPR74. As NPFF modulates morphine analgesia $(121,122)$, the hyperalgesic and anti-morphine-induced analgesic effects of endogenous RFamide peptides were analyzed in mice. All of the peptides

\section{REFERENCES}

1. Schally AV, Kastin AJ, Arimura A. The hypothalamus and reproduction. Am J Obstet Gynecol (1972) 114:423-42.

2. Moss RL, McCann SM. Induction of mating behavior in rats by luteinizing hormone-releasing factor. Science (1973) 181:177-9. doi:10.1126/ science.181.4095.177

3. Pfaff DW. Luteinizing hormone-releasing factor potentiates lordosis behavior in hypophysectomized ovariectomized female rats. Science (1973) 182:1148-9. doi:10.1126/science.182.4117.1148

4. Parhar I, Ogawa S, Kitahashi T. RFamide peptides as mediators in environmental control of GnRH neurons. Prog Neurobiol (2012) 98:176-96. doi:10.1016/j.pneurobio.2012.05.011

5. Ogawa S, Nathan FM, Parhar IS. Habenular kisspeptin modulates fear in the zebrafish. Proc Natl Acad Sci U S A (2014) 111:3841-6. doi:10.1073/ pnas. 1314184111 induced hyperalgesia and/or prevented morphine analgesia following the central administration. These results show that all endogenous RFamide peptides display pain-modulating properties and that GPR147 and GPR74 are essential players for these effects (120), suggesting potential use of RFamide peptides, namely, GnIH and kisspeptin, for the treatment of pain and stress-related disorders.

\section{SUMMARY AND CONCLUSION}

A variety of hypothalamic neuropeptides have been also identified as important regulators of social behaviors as neurotransmitter or neuromodulator (123). Expression of hypothalamic neuropeptides or activity of hypothalamic neurons also changes profoundly according to social environment to increase reproductive fitness (97). Social behaviors, such as affiliation, communication, and aggression, are closely associated with reproductive functions to ultimately achieve successful reproduction. We highlighted classical and recent findings regarding the role of $\mathrm{GnRH}$, kisspeptin and $\mathrm{GnIH}$, neuropeptides that are involved in gonadotropin secretion and in the regulation of social behaviors in fish, birds, and mammals and discussed their importance in future researches. The accumulating results suggest that these neuropeptides may directly regulate social behaviors by acting within the brain, besides regulating the HPG axis.

\section{AUTHOR CONTRIBUTIONS}

All authors listed have made substantial, direct, and intellectual contribution to the work and approved it for publication.

\section{FUNDING}

This work is supported by grants from Malaysian Ministry of Higher Education, FRGS/2/2010/ST/MUSM/03/2 and FRGS/1/2014/ST03/MUSM/02/1 (to SO and IP), Malaysian Ministry of Science, Technology, and Innovation, 02-02-10SF0044, 02-02-10-SF0161, and 02-02-10-SF0162 (to IP and SO), and Neuroscience Research Strength Grant from Monash University Malaysia (to IP).

6. Ubuka T, Mukai M, Wolfe J, Beverly R, Clegg S, Wang A, et al. RNA interference of gonadotropin-inhibitory hormone gene induces arousal in songbirds. PLoS One (2012) 7:e30202. doi:10.1371/journal.pone.0030202

7. Ubuka T, Bentley GE, Tsutsui K. Neuroendocrine regulation of gonadotropin secretion in seasonally breeding birds. Front Neurosci (2013) 7:38. doi:10.1677/JOE-08-0508

8. Ubuka T, Haraguchi S, Tobari Y, Narihiro M, Ishikawa K, Hayashi T, et al. Hypothalamic inhibition of socio-sexual behaviour by increasing neuroestrogen synthesis. Nat Commun (2014) 5:3061. doi:10.1038/ ncomms4061

9. Ubuka T, Mizuno T, Fukuda Y, Bentley GE, Wingfield JC, Tsutsui K. RNA interference of gonadotropin-inhibitory hormone gene induces aggressive and sexual behaviors in birds. Gen Comp Endocrinol (2013) 181:179-86. doi:10.1016/j.ygcen.2012.09.010

10. Adkins-Regan E. Hormones and Animal Social Behavior. Princeton, NJ, USA: Princeton University Press (2005). 
11. Matsuo H, Baba Y, Nair RM, Arimura A, Schally AV. Structure of the porcine LH- and FSH-releasing hormone. I. The proposed amino acid sequence. Biochem Biophys Res Commun (1971) 43:1334-9. doi:10.1016/ S0006-291X(71)80019-0

12. Burgus R, Butcher M, Amoss M, Ling N, Monahan M, Rivier J, et al. Primary structure of the ovine hypothalamic luteinizing hormone-releasing factor (LRF). Proc Natl Acad Sci U S A (1972) 69:278-82. doi:10.1073/ pnas.69.1.278

13. Jimenez-Liñan M, Rubin BS, King JC. Examination of guinea pig luteinizing hormone-releasing hormone gene reveals a unique decapeptide and existence of two transcripts in the brain. Endocrinology (1997) 138:4123-30. doi:10.1210/endo.138.10.5454

14. King JA, Millar RP. Structure of chicken hypothalamic luteinizing hormone-releasing hormone. I. Structural determination on partially purified material. J Biol Chem (1982) 257:10722-8.

15. Miyamoto K, Hasegawa Y, Minegishi T, Nomura M, Takahashi Y, Igarashi M, et al. Isolation and characterization of chicken hypothalamic luteinizing hormone-releasing hormone. Biochem Biophys Res Commun (1982) 107:820-7. doi:10.1016/0006-291X(82)90596-4

16. Powell JF, Zohar Y, Elizur A, Park M, Fischer WH, Craig AG, et al. Three forms of gonadotropin-releasing hormone characterized from brains of one species. Proc Natl Acad Sci U S A (1994) 91:12081-5. doi:10.1073/ pnas.91.25.12081

17. Ubuka T, Bentley GE. Identification, localization, and regulation of passerine GnRH-I messenger RNA. J Endocrinol (2009) 201:81-7. doi:10.1677/ JOE-08-0508

18. Ubuka T, Cadigan PA, Wang A, Liu J, Bentley GE. Identification of European starling GnRH-I precursor mRNA and its seasonal regulation. Gen Comp Endocrinol (2009) 162:301-6. doi:10.1016/j.ygcen.2009.04.001

19. Parhar IS. Cell migration and evolutionary significance of GnRH subtypes. Prog Brain Res (2002) 141:3-17. doi:10.1016/S0079-6123(02)41080-1

20. Miyamoto K, Hasegawa Y, Nomura M, Igarashi M, Kangawa K, Matsuo H. Identification of the second gonadotropin-releasing hormone in chicken hypothalamus: evidence that gonadotropin secretion is probably controlled by two distinct gonadotropin-releasing hormones in avian species. Proc Natl Acad Sci U S A (1984) 81:3874-8. doi:10.1073/pnas.81.12.3874

21. Millar RP. GnRH II and type II GnRH receptors. Trends Endocrinol Metab (2003) 14:35-43. doi:10.1016/S1043-2760(02)00016-4

22. Sherwood N, Eiden L, Brownstein M, Spiess J, Rivier J, Vale W. Characterization of a teleost gonadotropin-releasing hormone. Proc Natl Acad Sci U S A (1983) 80:2794-8. doi:10.1073/pnas.80.9.2794

23. Parhar I, Pfaff D, Schwanzel-Fukuda M. Genes and behavior as studied through gonadotropin-releasing hormone $(\mathrm{GnRH})$ neurons: comparative and functional aspects. Cell Mol Neurobiol (1995) 15:107-16. doi:10.1007/ BF02069561

24. Maney DL, Richardson RD, Wingfield JC. Central administration of chicken gonadotropin-releasing hormone-II enhances courtship behavior in a female sparrow. Horm Behav (1997) 32:11-8. doi:10.1006/hbeh.1997.1399

25. Kauffman AS, Rissman EF. A critical role for the evolutionarily conserved gonadotropin-releasing hormone II: mediation of energy status and female sexual behavior. Endocrinology (2004) 145:3639-46. doi:10.1210/ en.2004-0148

26. Barnett DK, Bunnell TM, Millar RP, Abbott DH. Gonadotropin-releasing hormone II stimulates female sexual behavior in marmoset monkeys. Endocrinology (2005) 147:615-23. doi:10.1210/en.2005-0662

27. Kauffman A, Wills A, Millar R, Rissman E. Evidence that the type-2 gonadotrophin-releasing hormone $(\mathrm{GnRH})$ receptor mediates the behavioural effects of GnRH-II on feeding and reproduction in musk shrews. J Neuroendocrinol (2005) 17:489-97. doi:10.1111/j.1365-2826.2005.01334.x

28. Volkoff H, Peter RE. Actions of two forms of gonadotropin releasing hormone and a GnRH antagonist on spawning behavior of the goldfish Carassius auratus. Gen Comp Endocrinol (1999) 116:347-55. doi:10.1006/ gcen.1999.7377

29. Ogawa S, Akiyama G, Kato S, Soga T, Sakuma Y, Parhar IS. Immunoneutralization of gonadotropin-releasing hormone type-III suppresses male reproductive behavior of cichlids. Neurosci Lett (2006) 403:201-5. doi:10.1016/j.neulet.2006.02.041
30. Okuyama T, Yokoi S, Abe H, Isoe Y, Suehiro Y, Imada H, et al. A neural mechanism underlying mating preferences for familiar individuals in medaka fish. Science (2014) 343:91-4. doi:10.1126/science.1244724

31. Lee JH, Miele ME, Hicks DJ, Phillips KK, Trent JM, Weissman BE, et al. KiSS-1, a novel human malignant melanoma metastasis-suppressor gene. J Natl Cancer Inst (1996) 88:1731-7. doi:10.1093/jnci/88.23.1731

32. Stafford LJ, Xia C, Ma W, Cai Y, Liu M. Identification and characterization of mouse metastasis-suppressor KiSS1 and its G-protein-coupled receptor. Cancer Res (2002) 62:5399-404.

33. Ubuka T, Morgan K, Pawson AJ, Osugi T, Chowdhury VS, Minakata H, et al. Identification of human GnIH homologs, RFRP-1 and RFRP-3, and the cognate receptor, GPR147 in the human hypothalamic pituitary axis. PLoS One (2009) 4:e8400. doi:10.1371/journal.pone.0008400

34. Tsutsui K, Saigoh E, Ukena K, Teranishi H, Fujisawa Y, Kikuchi M, et al. A novel avian hypothalamic peptide inhibiting gonadotropin release. Biochem Biophys Res Commun (2000) 275:661-7. doi:10.1006/bbrc.2000.3350

35. Satake H, Hisada M, Kawada T, Minakata H, Ukena K, Tsutsui K. Characterization of a cDNA encoding a novel avian hypothalamic neuropeptide exerting an inhibitory effect on gonadotropin release. Biochem J (2001) 354:379-85. doi:10.1042/bj3540379

36. Biran J, Ben-Dor S, Levavi-Sivan B. Molecular identification and functional characterization of the kisspeptin/kisspeptin receptor system in lower vertebrates. Biol Reprod (2008) 79:776-86. doi:10.1095/biolreprod.107.066266

37. Kitahashi T, Ogawa S, Parhar IS. Cloning and expression of kiss 2 in the zebrafish and medaka. Endocrinology (2009) 150:821-31. doi:10.1210/en.2008-0940

38. Sawada K, Ukena K, Satake H, Iwakoshi E, Minakata H, Tsutsui K. Novel fish hypothalamic neuropeptide. Eur JBiochem (2002) 269:6000-8. doi:10.1046/j.1432-1033.2002.03351.x

39. Sakuma Y, Pfaff DW. LH-RH in the mesencephalic central grey can potentiate lordosis reflex of female rats. Nature (1980) 283:566-7. doi:10.1038/283566a0

40. Rivier C, Rivier J, Vale W. Effect of a potent GnRH antagonist and testosterone propionate on mating behavior and fertility in the male rat. Endocrinology (1981) 108:1998-2001. doi:10.1210/endo-108-4-1425

41. Wallen K, Maestripieri D, Mann DR. Effects of neonatal testicular suppression with a GnRH antagonist on social behavior in group-living juvenile rhesus monkeys. Horm Behav (1995) 29:322-37. doi:10.1006/hbeh.1995.1023

42. Huxsoll C, Price E, Adams T. Testis function, carcass traits, and aggressive behavior of beef bulls actively immunized against gonadotropin-releasing hormone. J Anim Sci (1998) 76:1760-6.

43. Price EO, Adams TE, Huxsoll CC, Borgwardt RE. Aggressive behavior is reduced in bulls actively immunized against gonadotropin-releasing hormone. J Anim Sci (2003) 81:411-5. doi:/2003.812411x

44. Zamaratskaia G, Rydhmer L, Andersson HK, Chen G, Lowagie S, Andersson $\mathrm{K}$, et al. Long-term effect of vaccination against gonadotropin-releasing hormone, using Improvac ${ }^{\mathrm{TM}}$, on hormonal profile and behaviour of male pigs. Anim Reprod Sci (2008) 108:37-48. doi:10.1016/j.anireprosci.2007.07.001

45. Granger A, Ngô-Muller V, Bleux C, Guigon C, Pincas H, Magre S, et al. The promoter of the rat gonadotropin-releasing hormone receptor gene directs the expression of the human placental alkaline phosphatase reporter gene in gonadotrope cells in the anterior pituitary gland as well as in multiple extrapituitary tissues. Endocrinology (2004) 145:983-93. doi:10.1210/en.2003-0881

46. Albertson AJ, Navratil A, Mignot M, Dufourny L, Cherrington B, Skinner DC. Immunoreactive GnRH type I receptors in the mouse and sheep brain. J Chem Neuroanat (2008) 35:326-33. doi:10.1016/j.jchemneu.2008.03.004

47. Wen S, Götze IN, Mai O, Schauer C, Leinders-Zufall T, Boehm U. Genetic identification of $\mathrm{GnRH}$ receptor neurons: a new model for studying neural circuits underlying reproductive physiology in the mouse brain. Endocrinology (2011) 152:1515-26. doi:10.1210/en.2010-1208

48. Blake CB, Meredith M. Selective enhancement of main olfactory input to the medial amygdala by GnRH. Brain Res (2010) 1317:46-59. doi:10.1016/j. brainres.2009.10.078

49. Warnock JK, Bundren JC. Anxiety and mood disorders associated with gonadotropin-releasing hormone agonist therapy. Psychopharmacol Bull (1997) 33:311.

50. Smeenk J, Verhaak C, Eugster A, Van Minnen A, Zielhuis G, Braat D. The effect of anxiety and depression on the outcome of in-vitro fertilization. Hum Reprod (2001) 16:1420-3. doi:10.1093/humrep/16.7.1420 
51. Umathe SN, Bhutada PS, Jain NS, Dixit PV, Wanjari MM. Effects of central administration of gonadotropin-releasing hormone agonists and antagonist on elevated plus-maze and social interaction behavior in rats. Behav Pharmacol (2008) 19:308-16. doi:10.1097/FBP.0b013e328308f1fb

52. Umathe SN, Bhutada PS, Jain NS, Shukla NR, Mundhada YR, Dixit PV. Gonadotropin-releasing hormone agonist blocks anxiogenic-like and depressant-like effect of corticotrophin-releasing hormone in mice. Neuropeptides (2008) 42:399-410. doi:10.1016/j.npep.2008.04.005

53. Holmes A, Heilig M, Rupniak NMJ, Steckler T, Griebel G. Neuropeptide systems as novel therapeutic targets for depression and anxiety disorders. Trends Pharmacol Sci (2003) 24:580-8. doi:10.1016/j.tips.2003.09.011

54. Thind KK, Boggan JE, Goldsmith PC. Interactions between vasopressin- and gonadotropin-releasing-hormone-containing neuroendocrine neurons in the monkey supraoptic nucleus. Neuroendocrinology (1991) 53:287-97. doi:10.1159/000125731

55. Boczek-Leszczyk E, Stempniak B, Juszczak M. Vasopressin release from the rat hypothalamo-neurohypophysial system: effects of gonadotrophin-releasing hormone $(\mathrm{GnRH})$, its analogues and melatonin. J Physiol Pharmacol (2010) 61:459-66.

56. Matsuda K, Nakamura K, Shimakura S, Miura T, Kageyama H, Uchiyama $\mathrm{M}$, et al. Inhibitory effect of chicken gonadotropin-releasing hormone II on food intake in the goldfish, Carassius auratus. Horm Behav (2008) 54:83-9. doi:10.1016/j.yhbeh.2008.01.011

57. Kang KS, Shimizu K, Azuma M, Ui Y, Nakamura K, Uchiyama M, et al. Gonadotropin-releasing hormone II (GnRH II) mediates the anorexigenic actions of $\alpha$-melanocyte-stimulating hormone ( $\alpha$-MSH) and corticotropin-releasing hormone (CRH) in goldfish. Peptides (2011) 32:31-5. doi:10.1016/j.peptides.2010.10.013

58. Kotani M, Detheux M, Vandenbogaerde A, Communi D, Vanderwinden JM, Le Poul E, et al. The metastasis suppressor gene KiSS-1 encodes kisspeptins, the natural ligands of the orphan G protein-coupled receptor GPR54. J Biol Chem (2001) 276:34631-6. doi:10.1074/jbc.M104847200

59. Ohtaki T, Shintani Y, Honda S, Matsumoto H, Hori A, Kanehashi K, et al. Metastasis suppressor gene KiSS-1 encodes peptide ligand of a G-proteincoupled receptor. Nature (2001) 411:613-7. doi:10.1038/35079135

60. Gopurappilly R, Ogawa S, Parhar IS. Functional significance of GnRH and kisspeptin, and their cognate receptors in teleost reproduction. Front Endocrinol (2013) 4:24. doi:10.3389/fendo.2013.00024

61. Joseph NT, Tello JA, Bedecarrats GY, Millar RP. Reproductive neuropeptides: prevalence of GnRH and KNDy neural signalling components in a model avian, Gallus gallus. Gen Comp Endocrinol (2013) 190:134-43. doi:10.1016/j. ygcen.2013.05.018

62. de Roux N, Genin E, Carel J, Matsuda F, Chaussain J, Milgrom E. Hypogonadotropic hypogonadism due to loss of function of the KiSS1derived peptide receptor GPR54. Proc Natl Acad Sci US A (2003) 100:10972-6. doi:10.1371/journal.pone.0057972

63. Seminara SB, Messager S, Chatzidaki EE, Thresher RR, Acierno JS Jr, Shagoury JK, et al. The GPR54 gene as a regulator of puberty. $N$ Engl J Med (2003) 349:1614-27. doi:10.1056/NEJMoa035322

64. Kinoshita M, Tsukamura H, Adachi S, Matsui H, Uenoyama Y, Iwata K, et al. Involvement of central metastin in the regulation of preovulatory luteinizing hormone surge and estrous cyclicity in female rats. Endocrinology (2005) 146:4431-6. doi:10.1210/en.2005-0195

65. Smith JT, Popa SM, Clifton DK, Hoffman GE, Steiner RA. Kiss1 neurons in the forebrain as central processors for generating the preovulatory luteinizing hormone surge. J Neurosci (2006) 26:6687-94. doi:10.1523/ JNEUROSCI.1618-06.2006

66. Kauffman AS, Park JH, McPhie-Lalmansingh AA, Gottsch ML, Bodo C, Hohmann JG, et al. The kisspeptin receptor GPR54 is required for sexual differentiation of the brain and behavior. J Neurosci (2007) 27:8826-35. doi:10.1523/JNEUROSCI.2099-07.2007

67. Tang H, Liu Y, Luo D, Ogawa S, Yin Y, Li S, et al. The kiss/kissr systems are dispensable for zebrafish reproduction: evidence from gene knockout studies. Endocrinology (2015) 156:589-99. doi:10.1210/en.2014-1204

68. Ogawa S, Ng KW, Ramadasan PN, Nathan FM, Parhar IS. Habenular Kiss1 neurons modulate the serotonergic system in the brain of zebrafish. Endocrinology (2012) 153:2398-407. doi:10.1210/en.2012-1062
69. Kim J, Semaan SJ, Clifton DK, Steiner RA, Dhamija S, Kauffman AS. Regulation of Kiss1 expression by sex steroids in the amygdala of the rat and mouse. Endocrinology (2011) 152:2020-30. doi:10.1210/en.2010-1498

70. Csabafi K, Jászberényi M, Bagosi Z, Lipták N, Telegdy G. Effects of kisspeptin-13 on the hypothalamic-pituitary-adrenal axis, thermoregulation, anxiety and locomotor activity in rats. Behav Brain Res (2013) 241:56-61. doi:10.1016/j.bbr.2012.11.039

71. Tanaka M, Csabafi K, Telegdy G. Neurotransmissions of antidepressant-like effects of kisspeptin-13. Regul Pept (2013) 180:1-4. doi:10.1016/j. regpep.2012.08.017

72. Telegdy G, Adamik Á. The action of kisspeptin-13 on passive avoidance learning in mice. Involvement of transmitters. Behav Brain Res (2013) 243:300-5. doi:10.1016/j.bbr.2013.01.016

73. Nathan FM, Ogawa S, Parhar IS. Kisspeptin1 modulates odorant-evoked fear response via two serotonin receptor subtypes (5-HT1A and 5-HT2) in zebrafish. J Neurochem (2015) 133:870-8. doi:10.1111/jnc.13105

74. Ubuka T, Son YL, Tsutsui K. Molecular, cellular, morphological, physiologi$\mathrm{cal}$ and behavioral aspects of gonadotropin-inhibitory hormone. Gen Comp Endocrinol (2015) 227:27-50. doi:10.1016/j.ygcen.2015.09.009

75. Kriegsfeld LJ, Mei DF, Bentley GE, Ubuka T, Mason AO, Inoue K, et al. Identification and characterization of a gonadotropin-inhibitory system in the brains of mammals. Proc Natl Acad Sci U S A (2006) 103:2410-5. doi:10.1073/pnas.0511003103

76. Ubuka T, Tsutsui K. Evolution of gonadotropin-inhibitory hormone receptor and its ligand. Gen Comp Endocrinol (2014) 209:148-61. doi:10.1016/j. ygcen.2014.09.002

77. Ogawa S, Parhar IS. Structural and functional divergence of gonadotropin-inhibitory hormone from jawless fish to mammals. Front Endocrinol (2014) 5:177. doi:10.3389/fendo.2014.00177

78. Ubuka T, Kim S, Huang YC, Reid J, Jiang J, Osugi T, et al. Gonadotropininhibitory hormone neurons interact directly with gonadotropin-releasing hormone-I and -II neurons in European starling brain. Endocrinology (2008) 149:268-78. doi:10.1210/en.2007-0983

79. Ubuka T, Inoue K, Fukuda Y, Mizuno T, Ukena K, Kriegsfeld LJ, et al. Identification, expression, and physiological functions of Siberian hamster gonadotropin-inhibitory hormone. Endocrinology (2012) 153:373-85. doi:10.1210/en.2011-1110

80. Ubuka T, Bentley GE, Ukena K, Wingfield JC, Tsutsui K. Melatonin induces the expression of gonadotropin-inhibitory hormone in the avian brain. Proc Natl Acad Sci U S A (2005) 102:3052-7. doi:10.1073/ pnas.0403840102

81. Tobari Y, Son YL, Ubuka T, Hasegawa Y, Tsutsui K. A new pathway mediating social effects on the endocrine system: female presence acting via norepinephrine release stimulates gonadotropin-inhibitory hormone in the paraventricular nucleus and suppresses luteinizing hormone in quail. J Neurosci (2014) 34:9803-11. doi:10.1523/JNEUROSCI.3706-13.2014

82. Kirby ED, Geraghty AC, Ubuka T, Bentley GE, Kaufer D. Stress increases putative gonadotropin inhibitory hormone and decreases luteinizing hormone in male rats. Proc Natl Acad Sci U S A (2009) 106:11324-9. doi:10.1073/ pnas.0901176106

83. Son YL, Ubuka T, Narihiro M, Fukuda Y, Hasunuma I, Yamamoto K, et al. Molecular basis for the activation of gonadotropin-inhibitory hormone gene transcription by corticosterone. Endocrinology (2014) 155:1817-26. doi:10.1210/en.2013-2076

84. Tena-Sempere M, Kisspeptins AJ, Kastin H, Vaudry (Eds.), Handbook of Biologically Active Peptides. Academic Press, London: Section on Brain Peptides, (2012) p. 819-27.

85. Lehman MN, Hileman SM, Goodman RL. Neuroanatomy of the kisspeptin signaling system in mammals: comparative and developmental aspects. $A d v$ Exp Med Biol (2013) 784:27-62. doi:10.1007/978-1-4614-6199-9_3

86. Tsutsui K, Ubuka T. Gonadotropin-inhibitory hormone. In: Kastin AJ, Vaudry H, editors. Handbook of Biologically Active Peptides. Section on Brain Peptides. London: Academic Press (2012). p. 802-11.

87. Escobar S, Servili A, Espigares F, Gueguen MM, Brocal I, Felip A, et al. Expression of kisspeptins and kiss receptors suggests a large range of functions for kisspeptin systems in the brain of the European sea bass. PLoS One (2013) 8:e70177. doi:10.1371/journal.pone.0070177 
88. Qi X, Zhou W, Li S, Lu D, Yi S, Xie R, et al. Evidences for the regulation of $\mathrm{GnRH}$ and GTH expression by GnIH in the goldfish, Carassius auratus. Mol Cell Endocrinol (2013) 366:9-20. doi:10.1016/j.mce.2012.11.001

89. Parhar IS, Ogawa S, Sakuma Y. Laser-captured single digoxigenin-labeled neurons of gonadotropin-releasing hormone types reveal a novel G protein-coupled receptor (Gpr54) during maturation in cichlid fish. Endocrinology (2004) 145:3613-8.

90. Grone BP, Maruska KP, Korzan WJ, Fernald RD. Social status regulates kisspeptin receptor mRNA in the brain of Astatotilapia burtoni. Gen Comp Endocrinol (2010) 169:98-107. doi:10.1016/j.ygcen.2010.07.018

91. Bentley GE, Perfito N, Ukena K, Tsutsui K, Wingfield JC. Gonadotropininhibitory peptide in song sparrows (Melospiza melodia) in different reproductive conditions, and in house sparrows (Passer domesticus) relative to chicken-gonadotropin-releasing hormone. J Neuroendocrinol (2003) 15:794-802. doi:10.1046/j.1365-2826.2003.01062.x

92. Bentley GE, Jensen JP, Kaur GJ, Wacker DW, Tsutsui K, Wingfield JC. Rapid inhibition of female sexual behavior by gonadotropin-inhibitory hormone (GnIH). Horm Behav (2006) 49:550-5. doi:10.1016/j.yhbeh.2005.12.005

93. Johnson MA, Tsutsui K, Fraley GS. Rat RFamide-related peptide-3 stimulates GH secretion, inhibits LH secretion, and has variable effects on sex behavior in the adult male rat. Horm Behav (2007) 51:171-80. doi:10.1016/j. yhbeh.2006.09.009

94. Piekarski DJ, Zhao S, Jennings KJ, Iwasa T, Legan SJ, Mikkelsen JD, et al. Gonadotropin-inhibitory hormone reduces sexual motivation but not lordosis behavior in female Syrian hamsters (Mesocricetus auratus). Horm Behav (2013) 64:501-10. doi:10.1016/j.yhbeh.2013.06.006

95. Clarke IJ, Smith JT, Henry BA, Oldfield BJ, Stefanidis A, Millar RP, et al. Gonadotropin-inhibitory hormone is a hypothalamic peptide that provides a molecular switch between reproduction and feeding. Neuroendocrinology (2012) 95:305-16. doi:10.1159/000332822

96. Wingfield JC, Whaling CS, Marler PR. Communication in vertebrate aggression and reproduction: the role of hormones. In: Knobil E, Neil JD, editors. The Physiology of Reproduction. New York, NY: Raven Press (1994). p. 303-42.

97. Maruska KP, Fernald RD. Social regulation of gene expression in the hypothalamic-pituitary-gonadal axis. Physiology (Bethesda) (2011) 26:412-23. doi:10.1152/physiol.00032.2011

98. Bentley GE, Wingfield JC, Morton ML, Ball GF. Stimulatory effects on the reproductive axis in female songbirds by conspecific and heterospecific male song. Horm Behav (2000) 37:179-89. doi:10.1006/hbeh.2000.1573

99. Maney DL, Goode CT, Lake JI, Lange HS, O’Brien S. Rapid neuroendocrine responses to auditory courtship signals. Endocrinology (2007) 148:5614-23. doi:10.1210/en.2007-0879

100. Calisi RM, Díaz-Muñoz SL, Wingfield JC, Bentley GE. Social and breeding status are associated with the expression of GnIH. Genes Brain Behav (2011) 10:557-64. doi:10.1111/j.1601-183X.2011.00693.x

101. Keller M, Baum MJ, Brock O, Brennan PA, Bakker J. The main and the accessory olfactory systems interact in the control of mate recognition and sexual behavior. Behav Brain Res (2009) 200:268-76. doi:10.1016/j.bbr.2009.01.020

102. Karlson P, Luscher M. 'Pheromones': a new term for a class of biologically active substances. Nature (1959) 183:55-6. doi:10.1038/183055a0

103. Jouhanneau M, Szymanski L, Martini M, Ella A, Keller M. Kisspeptin: a new neuronal target of primer pheromones in the control of reproductive function in mammals. Gen Comp Endocrinol (2013) 188:3-8. doi:10.1016/j. ygcen.2013.03.008

104. Vandenbergh JG. Male odor accelerates female sexual maturation in mice. Endocrinology (1969) 84:658-60. doi:10.1210/endo-84-3-658

105. De Bond JA, Li Q, Millar RP, Clarke IJ, Smith JT. Kisspeptin signaling is required for the luteinizing hormone response in anestrous ewes following the introduction of males. PLoS One (2013) 8:e57972. doi:10.1371/journal. pone. 0057972

106. Murata K, Wakabayashi Y, Sakamoto K, Tanaka T, Takeuchi Y, Mori Y, et al. Effects of brief exposure of male pheromone on multiple-unit activity at close proximity to kisspeptin neurons in the goat arcuate nucleus. J Reprod Dev (2011) 57:197-202. doi:10.1262/jrd.10-070E

107. Mori Y, Nishihara M, Tanaka T, Shimizu T, Yamaguchi M, Takeuchi Y, et al. Chronic recording of electrophysiological manifestation of the hypothalamic gonadotropin-releasing hormone pulse generator activity in the goat. Neuroendocrinology (1991) 53:392-5. doi:10.1159/000125746
108. Brain SD, Cox HM. Neuropeptides and their receptors: innovative science providing novel therapeutic targets. Br J Pharmacol (2006) 147:S202-11. doi:10.1038/sj.bjp.0706461

109. Mathew SJ, Manji HK, Charney DS. Novel drugs and therapeutic targets for severe mood disorders. Neuropsychopharmacology (2008) 33:2080-92. doi:10.1038/sj.npp.1301652

110. Lee DK, George SR, O'Dowd BF. Novel G-protein-coupled receptor genes expressed in the brain: continued discovery of important therapeutic targets. Expert Opin Ther Targets (2002) 6:185-202. doi:10.1517/14728222.6.2.185

111. Findeisen M, Rathmann D, Beck-Sickinger AG. RFamide peptides: structure, function, mechanisms and pharmaceutical potential. Pharmaceuticals (2011) 4:1248-80. doi:10.3390/ph4091248

112. Jayasena CN, Nijher GMK, Chaudhri OB, Murphy KG, Ranger A, Lim A, et al. Subcutaneous injection of kisspeptin-54 acutely stimulates gonadotropin secretion in women with hypothalamic amenorrhea, but chronic administration causes tachyphylaxis. J Clin Endocrinol Metab (2009) 94:4315-23. doi:10.1210/jc.2009-0406

113. Jayasena C, Nijher G, Abbara A, Murphy K, Lim A, Patel D, et al. Twiceweekly administration of kisspeptin-54 for 8 weeks stimulates release of reproductive hormones in women with hypothalamic amenorrhea. Clin Pharmacol Ther (2010) 88:840-7. doi:10.1038/clpt.2010.204

114. Millar RP, Newton CL. Current and future applications of GnRH, kisspeptin and neurokinin B analogues. Nat Rev Endocrinol (2013) 9:451-66. doi:10.1038/nrendo.2013.120

115. Young J, George JT, Tello JA, Francou B, Bouligand J, Guiochon-Mantel A, et al. Kisspeptin restores pulsatile LH secretion in patients with neurokinin B signaling deficiencies: physiological, pathophysiological and therapeutic implications. Neuroendocrinology (2013) 97:193-202. doi:10.1159/000336376

116. Soga T, Wong DW, Clarke IJ, Parhar IS. Citalopram (antidepressant) administration causes sexual dysfunction in male mice through RF-amide related peptide in the dorsomedial hypothalamus. Neuropharmacology (2010) 59:77-85. doi:10.1016/j.neuropharm.2010.03.018

117. Osugi T, Daukss D, Gazda K, Ubuka T, Kosugi T, Nozaki M, et al. Evolutionary origin of the structure and function of gonadotropin-inhibitory hormone: insights from lampreys. Endocrinology (2012) 153:2362-74. doi:10.1210/ en.2011-2046

118. Osugi T, Okamura T, Son YL, Ohkubo M, Ubuka T, Henmi Y, et al. Evolutionary origin of GnIH and NPFF in chordates: insights from novel amphioxus RFamide peptides. PLoS One (2014) 9:e100962. doi:10.1371/ journal.pone. 0100962

119. Fredriksson R, Lagerström MC, Lundin LG, Schiöth HB. The G-proteincoupled receptors in the human genome form five main families. Phylogenetic analysis, paralogon groups, and fingerprints. Mol Pharmacol (2003) 63:1256-72. doi:10.1124/mol.63.6.1256

120. Elhabazi K, Humbert JP, Bertin I, Schmitt M, Bihel F, Bourguignon JJ, et al. Endogenous mammalian RF-amide peptides, including PrRP, kisspeptin and $26 \mathrm{RFa}$, modulate nociception and morphine analgesia via NPFF receptors. Neuropharmacology (2013) 75:164-71. doi:10.1016/j. neuropharm.2013.07.012

121. Panula P, Kalso E, Nieminen M-L, Kontinen VK, Brandt A, Pertovaara A. Neuropeptide FF and modulation of pain. Brain Res (1999) 848:191-6. doi:10.1016/S0006-8993(99)02044-2

122. Yang H-YT, Tao T, Iadarola MJ. Modulatory role of neuropeptide FF system in nociception and opiate analgesia. Neuropeptides (2008) 42:1-18. doi:10.1016/j.npep.2007.06.004

123. Insel TR, Young LJ. Neuropeptides and the evolution of social behavior. Curr Opin Neurobiol (2000) 10:784-9. doi:10.1016/S0959-4388(00)00146-X

Conflict of Interest Statement: The authors declare that the research was conducted in the absence of any commercial or financial relationships that could be construed as a potential conflict of interest.

Copyright $\odot 2016$ Parhar, Ogawa and Ubuka. This is an open-access article distributed under the terms of the Creative Commons Attribution License (CC BY). The use, distribution or reproduction in other forums is permitted, provided the original author(s) or licensor are credited and that the original publication in this journal is cited, in accordance with accepted academic practice. No use, distribution or reproduction is permitted which does not comply with these terms. 